\title{
Dampak Sosial Relokasi Pedagang Kaki Lima di Kawasan Wisata Kuliner Kota Tomohon
}

\section{Social Impact of Relocation on Street Vendors in Tomohon Culinary Tourism Site}

\author{
Reynaldo Christian Aotama ${ }^{1 *}$, Deavy Rosaline Henny Klavert ${ }^{2}$ \\ Fakultas Ekonomi, Universitas Sariputra Indonesia Tomohon, Indonesia \\ 1 reynaldoaotama@unsrittomohon.ac.id; 2 deavyklavert@unsrittomohon.ac.id \\ *Penulis koresponden
}

\begin{abstract}
Abstrak
Relokasi sebagai upaya penataan dan pengembangan usaha pedagang kaki lima sebagai salah satu sektor informal perlu dilakukan dengan mempertimbangkan beberapa faktor agar dapat terlaksana dengan baik, salah satunya adalah lingkungan sosial pedagang itu sendiri. Tujuan dari penelitian ini adalah untuk mengetahui dampak relokasi terhadap kondisi lingkungan sosial pedagang di Kawasan Wisata Kuliner Kota Tomohon. Jenis penelitian ini adalah penelitian deskriptif kualitatif dengan teknik pengumpulan data yaitu wawancara mendalam, observasi, dan dokumentasi. Hasil dari penelitian ini menunjukkan bahwa dampak dari relokasi terhadap kondisi sosial pedagang secara keseluruhan mengalami peningkatan jika dibandingkan dengan keadaan pada lokasi sebelumnya dilihat dari beberapa aspek seperti kepastian dan jaminan hukum, keamanan dan ketertiban, kenyamanan dan kebersihan, persaingan antar pedagang, serta hubungan sosial antar pedagang. Meskipun demikian ada beberapa kendala yang dihadapi pedagang di lokasi relokasi terutama kurangnya perhatian pemerintah dalam proses peremajaan dan pengembangan lokasi yang berdampak pada semakin berkurangnya pedagang yang berjualan. Penelitian ini mengindikasikan pentingnya pengelolaan lokasi yang berkelanjutan untuk memberikan manfaat yang lebih besar sesuai fungsi dan peruntukannya.
\end{abstract}

Kata Kunci: Dampak sosial; Relokasi; PKL

\begin{abstract}
Relocation as a government effort in organizing and empowering the informal sector such as street vending needs to be executed in consideration of several aspects include its social impact to the livelihood of the street vendors. The aim of this study is to figure out the impact of relocation on vendors' social well-being in Culinary Tourism Site of the city of Tomohon. This study adopted qualitative descriptive method in which the data were collected through in-depth interview, observation, and documentation. The result shows an improvement in social wellbeing of the vendors as the impact of the relocation in terms of legal aspect, security and orderliness, comfort and hygiene, competition level, and social relation among vendors. However, some problems emerge particularly about the lack of sustainable support of the local government in renovating and developing the location which results in a decline numbers of vendors selling in Culinary Tourism Site. This result indicates the importance of a sustainable management from the government in order to achieve the main purpose of the relocation policy which is to accommodating, organizing, and empowering the street vendors.
\end{abstract}

Keywords: Social impact; Relocation; Street vending

\section{Pendahuluan}

Pembangunan suatu daerah sering diikuti dengan pertambahan penduduk yang berdampak pada meningkatnya permintaan terhadap lapangan pekerjaan. Ketidakseimbangan antara lapangan kerja formal yang tersedia dengan jumlah tenaga kerja yang ada mengakibatkan bertambahnya pengangguran yang mendorong masyarakat untuk bekerja pada sektor informal karena dianggap lebih mudah untuk dilakukan. Salah satu bentuk usaha di 
sektor informal yang paling diminati adalah Pedagang Kaki Lima (PKL). Menurut Peraturan Menteri Dalam Negeri Republik Indonesia No. 41 Tahun 2012 tentang Pedoman Penataan dan Pemberdayaan Pedagang Kaki Lima, PKL adalah "pelaku usaha yang melakukan usaha perdagangan dengan menggunakan sarana usaha bergerak maupun tidak bergerak, menggunakan prasarana kota, fasilitas sosial, fasilitas umum, lahan dan bangunan milik pemerintah dan/atau swasta yang bersifat sementara/tidak menetap".

PKL menjadi sandaran mata pencaharian bagi jutaan rakyat kecil yang tinggal di daerah perkotaan terutama di negara berkembang seperti Indonesia. Tidak dapat dipungkiri bahwa sektor informal seperti PKL dapat mengurangi pengangguran dan menjadi penyangga perekonomian. Pada tahun 2013, $70 \%$ perekonomian Indonesia ditopang oleh sektor informal dengan kontribusi sebesar 40\% pada Produk Domestik Bruto Indonesia (Detik Finance, 2013). Akan tetapi, terlepas dari peran dan fungsinya bagi perekonomian, PKL seringkali mendapat tanggapan negatif dari masyarakat karena dianggap mengganggu ketertiban dan kenyamanan di ruang publik seperti mengganggu aktivitas pejalan kaki, lalu lintas, estetika, kebersihan serta fungsi prasarana umum. Akan tetapi, pemerintah berusaha agar usaha PKL tidak dimatikan melainkan dibina, diatur, dan dikembangkan mengingat perannya sangat besar dalam menciptakan lapangan pekerjaan dan meningkatkan perekonomian (Susilowati \& Wangi, 2017).

Kota Tomohon adalah salah satu kota yang terus mengalami perkembangan pesat sejak ditetapkan sebagai daerah otonom pada Agustus 2003. Hal ini menjadi daya tarik usaha bagi masyarakat baik penduduk asli maupun pendatang yang dapat dilihat dari berkembangnya usaha kecil termasuk PKL. Meskipun berdasarkan informasi dari Dinas Koperasi dan UKM Kota Tomohon bahwa belum ada data yang pasti mengenai jumlah PKL di Kota Tomohon sampai tahun 2020, akan tetapi dapat terlihat dimana PKL semakin banyak ditemui di pusat-pusat perbelanjaan dan ruang publik di Kota Tomohon dengan menggunakan emperan toko, trotoar atau bahu jalan. Melihat kondisi berdagang para PKL yang semakin tidak teratur sehingga mengganggu tata kota dan aktivitas publik, maka mendorong Pemerintah Kota Tomohon untuk melakukan penataan PKL, salah satunya dengan menyediakan lokasi Kawasan Wisata Kuliner untuk menampung para pedagang kecil terutama yang berjualan produk kuliner.

Relokasi PKL dipandang sebagai salah satu upaya penataan dan pengelolaan PKL yang dapat menguntungkan semua pihak baik pedagang, pemerintah, masyarakat dan lingkungan. Relokasi merupakan upaya untuk memindahkan suatu objek dari tempat yang satu ke tempat yang lain yang dianggap lebih baik. Relokasi bukan hanya sekedar perpindahan tempat dari segi ruang geografis, tetapi juga menyangkut berbagai aspek seperti ekonomi, sosial, politik, serta budaya. Selanjutnya, dalam melakukan relokasi harus memperhatikan lokasi dan kualitas dari tempat relokasi yang baru karena akan berpengaruh pada akses usaha, jaringan sosial, dan peluang pasar (Prasetya \& Fauziah, 2016). Relokasi PKL dapat memberikan dampak baik positif maupun negatif. Dampak negatif dari relokasi adalah merugikan pedagang karena dapat memutuskan mata rantai dengan konsumen disebabkan oleh berpindahnya tempat dagang dan ketidakstabilan usaha karena proses adaptasi dengan peraturan baru atau pesaing baru dalam lokasi yang sama (Purnomo, 2016).

Walaupun demikian relokasi memberikan manfaat yaitu 1) Kemakmuran, seperti peningkatan pendapatan, biaya hidup lebih rendah, retribusi yang efisien, dan stabilitas perdagangan; 2) Kenyamanan, seperti lokasi yang lebih baik dan lebih sehat; 3) Stimulasi, yaitu memberikan suasana baru yang dapat mengurangi kejenuhan dan meningkatkan produktivitas; 4) Afiliasi, kemudahan berinteraksi antara pedagang satu dengan yang lain; 5) Moralitas, yaitu meningkatkan kesadaran pedagang dalam melakukan cara hidup yang baik, mengikuti aturan dan norma yang ada (Purnomo, 2016).

Setiap lokasi memiliki karakteristik yang berbeda dengan kelebihan dan kekurangan masing-masing. Untuk itu, pemilihan lokasi untuk relokasi sebaiknya mempertimbangkan banyak hal dari semua aspek baik lingkungan sosial, ekonomi, ataupun budaya sehingga lebih memungkinkan bagi kegiatan relokasi tersebut untuk berhasil (Purnomo, 2016). 
Selain itu, relokasi diharapkan dapat memperbaiki tata ruang kota, meningkatkan kualitas pelayanan dan daya tampung pedagang dan konsumen, sehingga dapat mengembangkan usaha PKL serta meningkatkan kesejahteraan pedagang (Prasetya \& Fauziah, 2016; Purnomo, 2016).

Relokasi yang dilakukan oleh Pemerintah Kota Tomohon sendiri dipandang belum memiliki daya tarik yang cukup bagi sebagian besar pedagang dimana masih terlihat banyak pedagang yang bertahan di tempattempat umum yang dianggap lebih strategis, bahkan semakin sedikit pedagang yang memilih untuk berjualan di lokasi ini. Ada banyak faktor yang dapat berpengaruh pada keberhasilan pelaksanaan relokasi PKL salah satunya adalah faktor lingkungan sosial seperti keamanan dan kenyamanan berjualan. Untuk itu diperlukan adanya analisis dampak sosial dari relokasi PKL di Kota Tomohon sehingga dapat diketahui seberapa efektif kebijakan relokasi memberikan manfaat sosial dan ekonomi bagi para pedagang itu sendiri sehingga memberikan dampak positif yang lebih besar bagi pengembangan usaha kecil pada sektor informal di Kota Tomohon.

Dampak sosial adalah perubahan kondisi pada kehidupan masyarakat yang disebabkan oleh adanya penerapan peraturan atau kebijakan baru, pelaksanaan program atau proyek, atau aktivitas pembangunan lainnya (Purnomo, 2016). Dampak sosial dari relokasi PKL dapat diukur dari tingkat kenyamanan yang dirasakan baik oleh pedagang maupun konsumen dalam hal keamanan, ketertiban, dan kebersihan termasuk interaksi sosial yang terjadi antar sesama pedagang maupun dengan konsumen (Prasetya \& Fauziah, 2016). Dampak sosial ekonomi dari relokasi PKL dapat dilihat dari sisi positif dan negatif. Jika dilakukan dengan baik dengan mempertimbangkan kepentingan semua pihak maka relokasi dapat memberikan dampak sosial yang positif. Dampak sosial berupa peningkatan kelayakan dan kenyamanan usaha, perubahan status PKL menjadi pedagang legal, serta memperbaiki tata kota dan keindahan suatu daerah. Sedangkan, jika tidak dilaksanakan dengan baik maka relokasi dapat berdampak negatif seperti penurunan pendapatan, meningkatkan biaya operasional, berkurangnya jaringan sosial, dan lain sebagainya (Heriyanto, 2012).

Berdasarkan latar belakang masalah tersebut, maka penelitian ini bertujuan untuk mengidentifikasi dampak sosial dari relokasi PKL di Kota Tomohon dari persepsi PKL. Mengingat keberadaan PKL sebagai salah satu isu strategis yang membutuhkan perhatian khusus dari pemerintah, maka penelitian ini diharapkan dapat menjadi bahan pertimbangan bagi semua pihak baik pemerintah maupun pelaku usaha dalam menjalankan kebijakan penataan PKL. Diharapkan dengan adanya penataan dan pengelolaan PKL yang lebih efektif dapat mendorong pengembangan usaha kecil di sektor informal dan peningkatan kesejahteraan para pelaku usaha sehingga dapat meningkatkan pertumbuhan ekonomi baik daerah maupun nasional.

\section{Metode}

Penelitian ini menggunakan metode deskriptif kualitatif. Penelitian kualitatif bertujuan untuk memahami subjek penelitian seperti perilaku, persepsi, motivasi atau tindakan secara menyeluruh dan lebih menekankan pada makna atau pemahaman yang mendalam mengenai suatu masalah yang disajikan dalam bentuk data kualitatif seperti gambar, kata, ataupun kejadian (Moleong, 2012). Adapun penelitian deskriptif merupakan penelitian yang menggambarkan atau mendeskripsikan suatu fenomena secara tepat dan akurat (Yusuf, 2017). Penelitian deskriptif kualitatif digunakan dalam penelitian ini untuk mendeskripsikan dan menganalisis lebih mendalam mengenai dampak sosial relokasi PKL di Kota Tomohon.

Adapun penelitian ini berfokus pada persepsi PKL mengenai dampak sosial relokasi. Fokus penelitian bertujuan untuk membatasi bidang inquiry penelitian kualitatif (Moleong, 2012). Instrumen dalam penelitian kualitatif adalah peneliti itu sendiri yang bertugas untuk menetapkan fokus penelitian, memilih subjek penelitian sebagai sumber data, mengumpulkan data, menilai kualitas data, melakukan analisis data dan menarik kesimpulan (Sugiyono, 2015).

Teknik pengumpulan data dalam penelitian ini adalah wawancara mendalam, observasi, dan dokumentasi. Observasi 
dilakukan dengan mengamati kejadiankejadian di lokasi. Adapun awancara menggunakan teknik wawancara mendalam dengan model semi-structured untuk mendapatkan informasi yang jelas dan menyeluruh, sedangkan dokumentasi dilakukan dengan mempelajari dokumendokumen baik berupa catatan, laporan, maupun literatur yang berhubungan dengan penelitian.

Penelitian ini menggunakan dua jenis data yaitu data primer dan sekunder. Data primer yaitu data yang didapat dari sumber langsung tanpa perantara, dimana dalam penelitian ini didapat melalui wawancara terhadap subjek penelitian. Subjek penelitian dalam penelitian ini adalah para PKL yang ada di Kota Tomohon yang telah direlokasi ke Kawasan Wisata Kuliner. Dalam penelitian kualitatif tidak menekankan pada kuantitas subjek penelitian melainkan kedalaman informasi yang diperoleh. Untuk itu digunakan teknik snowball sampling yaitu penambahan subjek penelitian akan berhenti ketika tidak ada lagi informasi baru dan data sudah jenuh. Adapun data sekunder yaitu data yang sudah ada, dalam penelitian ini didapat melalui catatan observasi, pengumpulan dokumen dan studi literatur yang berkaitan dengan penelitian.

Dalam penelitian kualitatif, analisis data dilakukan dalam empat tahap. Pertama, melakukan reduksi data dimana data yang terkumpul dipelajari, dirangkum, dan disederhanakan. Kedua, sajian data dimana data yang telah direduksi akan dipaparkan secara sistematis dalam bentuk uraian singkat atau teks naratif. Ketiga, verifikasi yaitu hasil yang didapatkan dalam penelitian harus benar-benar dapat dipertanggungjawabkan dan dipercaya. Keempat, penarikan kesimpulan dimana data yang telah dianalisis, direduksi, diverifikasi dan disajikan kemudian disimpulkan. Verifikasi data dalam penelitian kualitatif dapat dilakukan dengan metode triangulasi. Triangulasi bertujuan untuk mengurangi bias yang terjadi pada saat pengumpulan dan analisis data dengan melakukan pemeriksaan kebenaran dari data atau informasi yang diperoleh peneliti dari berbagai sudut pandang yang berbeda (Firdaus \& Zamzam, 2018).

Ada beberapa jenis teknik triangulasi yaitu sumber, metode, teori, dan peneliti
(Firdaus \& Zamzam, 2018). Akan tetapi, untuk menguji keabsahan data dalam penelitian ini akan digunakan triangulasi sumber dan metode. Triangulasi sumber dilakukan dengan membandingkan data yang diperoleh dari setiap subjek penelitian. Sedangkan triangulasi metode dilakukan dengan membandingkan data yang diperoleh dari hasil wawancara mendalam dengan hasil observasi, dan kemudian dibandingkan dengan hasil dokumentasi termasuk literatur yang digunakan.

\section{Hasil dan Pembahasan}

\section{Gambaran umum Kawasan Wisata Kuliner Kota Tomohon}

Kawasan Wisata Kuliner merupakan suatu lokasi usaha yang disediakan oleh Pemerintah Kota Tomohon melalui Dinas Koperasi dan UKM bagi para pelaku UMKM termasuk PKL yang bergerak di bidang kuliner. Lokasi ini bertempat di dekat pusat kota dengan akses transportasi umum yang memadai. Berdasarkan informasi dari Dinas Koperasi dan UKM Kota Tomohon, jumlah pedagang yang terdaftar di lokasi ini adalah 70 pedagang. Para pedagang yang berdagang di lokasi ini dilengkapi dengan beberapa fasilitas seperti stan atau kios, listrik, air, dan tempat parkir seperti yang terlihat pada Gambar 1. Tujuan disediakannya lokasi kawasan wisata kuliner ini adalah selain untuk mendorong perkembangan UMKM tetapi juga sebagai solusi penataan PKL di Kota Tomohon.

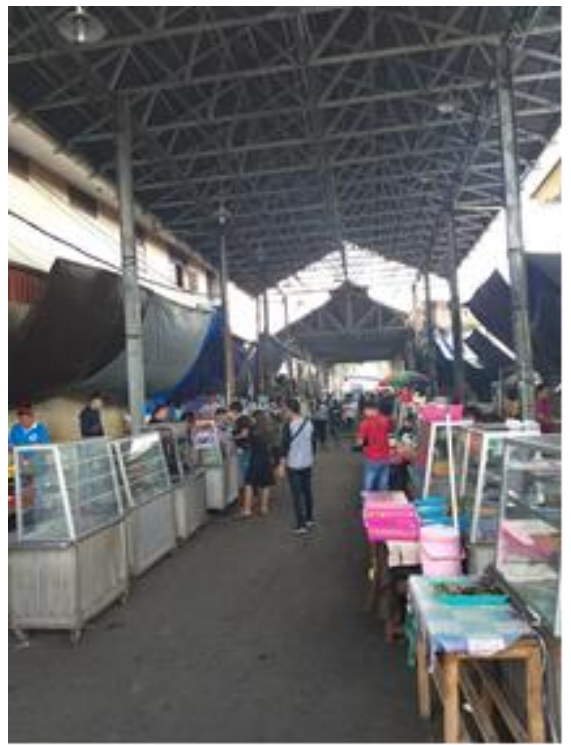

Gambar 1. Kondisi Pasar Tomohon

Pemerintah setempat berharap dengan adanya lokasi ini dapat menampung para 
pedagang yang sebelumnya berjualan di berbagai tempat umum yang bukan untuk peruntukannya seperti emperan toko/pusat perbelanjaan dan sepanjang bahu jalan utama. Dengan adanya lokasi ini diharapkan dapat tercipta ketertiban dan keindahan tatanan kota tanpa mengesampingkan kesejahteraan pedagang itu sendiri.

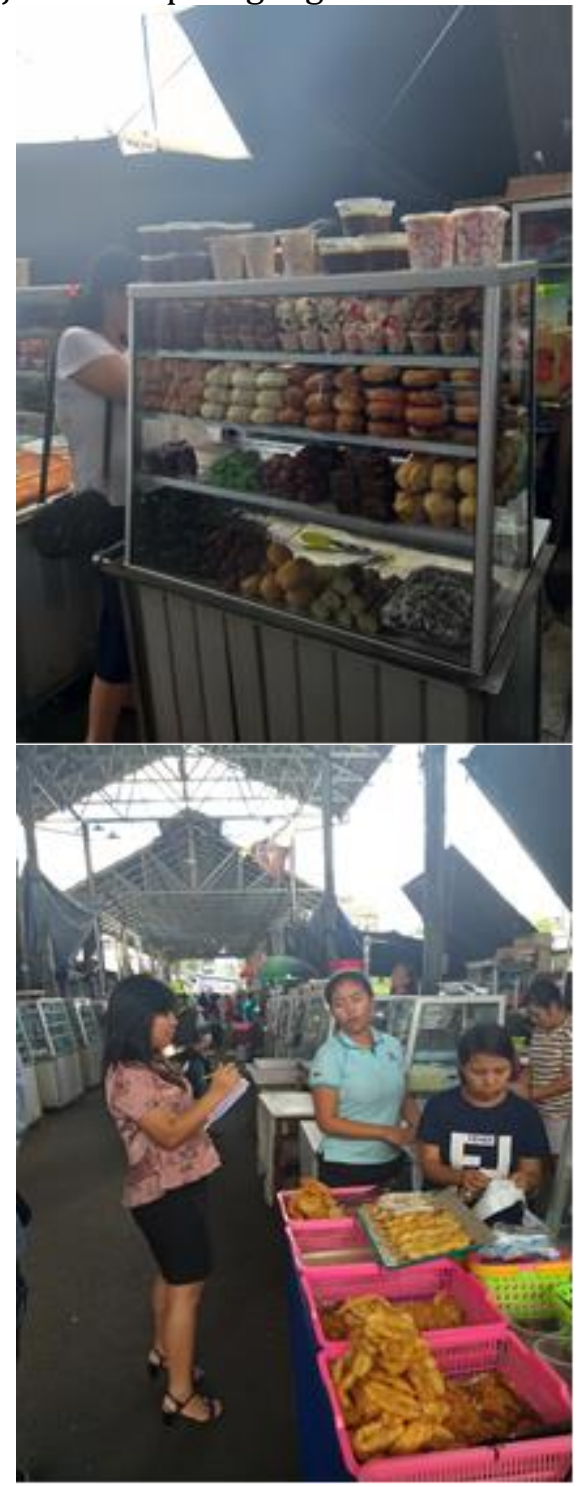

Gambar 2. Jenis dagangan di Pasar Tomohon

Untuk mendukung perkembangan para pelaku usaha, pemerintah juga menjadikan lokasi ini sebagai salah satu tujuan wisata di Kota Tomohon. Produk yang ditawarkan di lokasi ini beragam seperti berbagai jenis lauk-pauk, kue tradisional, jajanan pasar, bahkan makanan khas Sulawesi Utara seperti bubur manado dan mie cakalang.

\section{Karakteristik informan}

Pedagang yang menjadi informan dalam penelitian ini adalah PKL yang telah direlokasi ke Kawasan Wisata Kuliner Kota Tomohon yang berjumlah 10 orang. Sebagian besar dari mereka adalah wanita (70\%) dengan status sudah berkeluarga (100\%) dan rentang usia antara 30-50 tahun (80\%). Adapun latar belakang pendidikan sebagian besar hanya menyelesaikan pendidikan dasar (60\%). Jenis jualan mereka pun beragam seperti gorengan, aneka makanan penutup, martabak, bakso, lauk pauk, bubur manado, dan kue traditional (Gambar 2).

Rata-rata usaha mereka sudah berlangsung selama 4 sampai 5 tahun dengan durasi pekerjaan 12 jam per hari. Dari segi pendapatan, setiap pedagang memperoleh pendapatan yang bervariasi dimana rata-rata pedagang memperoleh pendapatan sekitar Rp. 9.000.000 dengan rata-rata keuntungan berkisar antara Rp. 2.000.000 - Rp. 6.000.000.

\section{Dampak sosial relokasi}

Dampak sosial dari relokasi PKL di Kota Tomohon yang dirasakan oleh pedagang sejak berpindah berjualan di lokasi Kawasan Wisata Kuliner Kota Tomohon adalah sebagai berikut:

1) Kepastian dan jaminan hukum

PKL merupakan salah satu sektor informal yang dianggap ilegal dan melanggar hukum karena berjualan di tempat-tempat umum tanpa izin usaha yang resmi. Dengan berjualan di lokasi Kawasan Wisata Kuliner yang disediakan oleh Pemerintah Kota Tomohon, maka PKL yang awalnya tidak memiliki status izin usaha yang jelas akan tercatat sebagai pedagang secara resmi oleh pemerintah dan mendapatkan izin usaha. Dengan adanya kepastian status usaha maka para pedagang mengakui bahwa mereka tidak perlu khawatir lagi akan adanya penggusuran atau penertiban yang dilakukan oleh pemerintah melalui Satuan Polisi Pamong Praja. Hal serupa ditemukan oleh Fatnawati (2013) dalam studinya pada pengelolaan PKL di Kota Surakarta dimana relokasi memberikan rasa tenang bagi pedagang dalam menjalankan usaha karena telah mendapatkan kepastian hukum dan keberadaan mereka dilindungi oleh pemerintah setempat. Selain itu, dengan adanya kejelasan status hukum membuat para pedagang terhindar dari stigma negatif yang selama ini melekat bagi PKL. Seperti yang dikemukakan oleh Handoyo and Widyaningrum (2015) bahwa relokasi dapat 
meningkatkan status sosial dan kualitas hidup para pedagang.

Kejelasan status hukum para pedagang juga membawa dampak positif bagi perkembangan usaha mereka. Beberapa pedagang mengakui bahwa sejak berjualan di lokasi Kawasan Wisata Kuliner dan terdaftar secara resmi di Dinas Koperasi dan UKM Kota Tomohon, mereka lebih mudah mendapatkan bantuan pemerintah ataupun mengajukan pinjaman di lembaga keuangan formal seperti bank. Hal ini sejalan dengan beberapa studi yang menyatakan bahwa formalisasi memungkinkan pelaku usaha untuk menikmati beberapa manfaat seperti akses keuangan pada lembaga formal, akses terhadap bantuan pemerintah, perlindungan sosial, dan berbagai layanan lainnya yang tidak dapat dirasakan ketika menjadi pelaku usaha sektor informal seperti PKL (Babbitt et al., 2015; McKenzie \& Seynabou Sakho, 2010; Rothenberg et al., 2016).

2) Keamanan dan ketertiban usaha

Salah satu masalah yang dihadapi oleh PKL adalah perasaan tidak aman dalam menjalankan usaha (Indira, 2014). Seperti yang dikemukakan oleh Widyaningrum (2009) bahwa PKL sangat rentan terhadap bentuk-bentuk eksploitasi dari pihak-pihak tertentu seperti "preman" dan organisasi PKL yang sering bertindak sebagai "perantara" dan "penjamin" kegiatan PKL agar tidak mengalami penggusuran. Dengan adanya relokasi PKL ke tempat yang disediakan dan diatur oleh pemerintah diakui para pedagang dapat memberikan rasa aman karena pemerintah selaku pengelola memberikan jaminan keamanan dan ketertiban. Para pedagang mengatakan bahwa dengan berjualan di lokasi yang disediakan pemerintah, mereka tidak perlu lagi membayar restribusi ilegal yang dilakukan oleh pihak-pihak yang tidak bertanggungjawab. Hal ini sejalan dengan hasil penelitian sebelumnya (Heriyanto, 2012) dimana relokasi bukan hanya meningkatkan keamanan usaha PKL karena terhindar dari gangguan preman tetapi juga meningkatkan ketertiban antar pedagang karena adanya peraturan keamanan yang dipatuhi oleh para pedagang.

3) Kenyamanan dan kebersihan usaha
Dengan disediakannya lokasi untuk berjualan serta fasilitas seperti stan atau kios maka meningkatkan kenyamanan usaha para pedagang karena mereka tidak perlu lagi mendorong ataupun bongkar pasang gerobak jualan lagi. Pedagang juga merasa lebih nyaman dengan adanya shelter sehingga mereka tidak perlu khawatir akan gangguan cuaca (Gambar 1). Adanya layanan kebersihan, penerangan, dan air bersih di lokasi usaha ini juga dirasa sangat membantu oleh para pedagang. Pengelolaan yang dilakukan oleh pihak pemerintah daerah melalui Dinas Koperasi dan UKM Kota Tomohon seperti penataan stan/kios serta pengelolaan limbah meningkatkan kerapian lokasi sehingga meningkatkan kenyamanan bagi para pedagang. Hal ini sejalan dengan penelitian terdahulu (Heriyanto, 2012; Purnomo, 2016) bahwa relokasi dan perbaikan fasilitas meningkatkan kehidupan sosial pedagang dalam empat aspek yaitu keamanan, kebersihan, penerangan, dan kemudahan.

Akan tetapi beberapa pedagang mengeluhkan perhatian pemerintah yang semakin berkurang terhadap operasional dan pengembangan lokasi Kawasan Wisata Kuliner Kota Tomohon. Melalui observasi langsung dapat terlihat bahwa ada fasilitasfasilitas yang memerlukan perhatian seperti ketersediaan toilet umum, perluasan lahan parkir, penambahan sarana kebersihan, dan sarana prasarana pendukung lainnya. Mereka mengakui bahwa hal tersebut sangat berdampak bagi kenyamanan bukan hanya para pedagang dalam berusaha tetapi juga bagi para pembeli. Tak dapat dipungkiri ada beberapa pedagang yang berpindah lokasi penjualan ke tempat lain. Adapula yang memilih untuk kembali berjualan di tempattempat umum yang lebih ramai pengunjung. Hal ini menjadi tanggung jawab pemerintah mengingat salah satu langkah penataan PKL yang diatur dalam Peraturan Menteri Dalam Negeri No. 41 Tahun 2012 adalah peremajaan lokasi PKL. Hal ini sejalan dengan penelitian terdahulu (Prasetya \& Fauziah, 2016) yang menemukan bahwa terkadang proses relokasi PKL tidak sejalan dengan tahapan relokasi yang ditetapkan dalam Peraturan Menteri Dalam Negeri Republik Indonesia No. 41 Tahun 2012 tentang Pedoman Penataan dan Pemberdayaan Pedagang Kaki Lima yaitu pendataan, pendaftaran, 
penetapan lokasi, pemindahan dan penghapusan lokasi, serta peremajaan lokasi PKL yang berdampak pada kegiatan relokasi yang tidak optimal dan berkesimbungan.

\section{4) Persaingan antar pedagang}

Salah satu ketakutan PKL untuk direlokasi selain kehilangan pelanggan adalah tingginya tingkat persaingan di lokasi relokasi (Novita, 2016). Relokasi dapat meningkatkan persaingan antar pedagang karena relokasi mengumpulkan banyak pedagang dalam satu lokasi yang sama dan menjual produk sejenis seperti halnya yang terjadi di lokasi Kawasan Wisata Kuliner Kota Tomohon. Pedagang mengakui bahwa berjualan di lokasi ini menjadi tantangan tersendiri terutama dalam hal persaingan antar pedagang. Tingginya persaingan mendorong pedagang untuk terus berusaha memberikan produk dengan kualitas dan tampilan yang baik agar dapat terus bersaing. Persaingan juga diakui bukan hanya akan datang dari pedagang lama akan tetapi ketersediaan lokasi usaha seperti ini menarik minat bagi usaha-usaha baru untuk masuk (Novita, 2016). Hal ini sejalan dengan yang dikemukakan oleh Purnomo (2016) mengemukakan bahwa relokasi menciptakan persaingan yang tinggi antar pedagang sehingga dibutuhkan strategi pengembangan usaha yang lebih baik.

\section{5) Hubungan sosial antar pedagang}

Persaingan antar pedagang yang tinggi di lokasi Kawasan Wisata Kuliner tidak menghalangi para pedagang untuk menjalin hubungan yang baik satu dengan yang lain. Para pedagang mengatakan bahwa mereka saling mengenal satu dengan yang lain dan seringkali terbentuk kerjasama dalam berjualan agar semua merasakan keuntungan. Apalagi penataan stan yang saling berdekatan tanpa adanya pemisah lebih meningkatkan komunikasi antar pedagang dan membentuk pola interaksi yang baik. Seperti yang dikemukakan pada studi sebelumnya (Rahayu et al., 2019) bahwa keadaan pedagang yang terkonsentrasi di satu tempat dan kondisi infrastruktur yang memadai dapat mendukung komunikasi yang baik antar pedagang. Kedekatan antar pedagang juga menimbulkan rasa kekeluargaan antar satu sama lain sehingga mendorong mereka membentuk suatu organisasi dalam hal ini koperasi. Menurut Heriyanto (2012), kerukunan antar pedagang dipercaya dapat mengurangi konflik dan kesenjangan yang dapat memberikan manfaat yang besar bagi perkembangan usaha.

\section{Kesimpulan}

Kegiatan sektor informal perkotaan seperti PKL merupakan isu yang kompleks sehingga membutuhkan penanganan yang komprehensif. Relokasi sebagai salah satu strategi penataan PKL perlu dilaksanakan dengan mempertimbangkan beberapa hal salah satunya adalah dampak sosial yang ditimbulkan bagi para pedagang itu sendiri. Relokasi yang dilakukan dengan baik secara keseluruhan dapat memberikan dampak sosial yang baik bagi para pedagang, sebaliknya pelaksanaan relokasi yang tidak teratur dapat membawa dampak negatif bagi keberlangsungan usaha PKL. Hasil penelitian ini menunjukkan bahwa relokasi PKL di Kawasan Wisata Kuliner di Kota Tomohon sebagian besar memberikan dampak sosial yang positif bagi para pedagang jika dibandingkan dengan keadaan pada lokasi berjualan sebelumnya seperti di pinggir jalan, emeperan toko atau di fasilitas publik lainnya. Dampak sosial yang dirasakan pedagang dapat dilihat dari beberapa aspek seperti kepastian dan jaminan hukum, keamanan dan ketertiban usaha, kenyamanan dan kebersihan, persaingan antar pedagang, dan hubungan sosial antar pedagang. Secara keseluruhan relokasi PKL di Kawasan Wisata Kuliner Kota Tomohon memberikan dampak sosial yang baik bagi para pedagang, meskipun demikian masih ada beberapa hal yang perlu mendapat perhatian pemerintah terutama mengenai peremajaan lokasi.

Untuk itu pemerintah setempat sebaiknya cepat tanggap dan konsisten dalam upaya mengembangkan dan mengelola usaha mikro yang ada di Kota Tomohon termasuk PKL melalui penyediaan lokasi usaha Kawasan Wisata Kuliner. Tahapan pelaksanaan relokasi sebaiknya tidak hanya berhenti sampai pada pelaksanaan saja, akan tetapi diperlukan adanya tindakan pengelolaan yang berkesinambungan sehingga dapat mencapai tujuan yang ditetapkan. Diharapkan dengan adanya penataan dan pengelolaan PKL yang lebih efektif dapat mendorong pengembangan usaha kecil di 
sektor informal dan peningkatan kesejahteraan para pelaku usaha sehingga dapat meningkatkan pertumbuhan ekonomi daerah dan nasional. Penelitian selanjutnya diharapkan dapat dilakukan dengan menganalisis dampak relokasi terhadap aspek yang lain seperti dampak ekonomi. Perlu juga dilakukan penelitian mendalam mengenai faktor-faktor yang dapat mendukung atau menghambat penataan dan pengembangan sektor informal khususnya pedagang kaki lima.

\section{Referensi}

Babbitt, L. G., Brown, D., \& Mazaheri, N. (2015). Gender, Entrepreneurship, and the Formal-Informal Dilemma: Evidence from Indonesia. World Development, 72, 163-174.

https://doi.org/10.1016/j.worlddev.20 15.02.019

Detik Finance. (2013). 70\% Pertumbuhan Ekonomi Indonesia Disumbang Sektor Informal. Diambil tanggal 26 November 2020 dari https://finance.detik.com/beritaekonomi-bisnis/d-2238328/70pertumbuhan-ekonomi-indonesiadisumbang-sektor-informal

Fatnawati, N. (2013). Dampak relokasi pedagang kaki lima berdasarkan Peraturan Daerah Kota Surakarta Nomor 3 Tahun 2008 tentang pengelolaan pedagang kaki lima terhadap usaha pedagang kaki lima di Surakarta. Universitas Negeri Semarang.

Firdaus, \& Zamzam, F. (2018). Aplikasi metodologi penelitian. Dee Publish.

Handoyo, E., \& Widyaningrum, N. R. (2015). Relocation as empowerment: Response, welfare, and life quality of street vendors after relocation. Jurnal Komunitas, 7(1), 31-43.

https://doi.org/10.15294/komunitas.v 7i1.34xx

Heriyanto, A. W. (2012). Dampak sosial ekonomi relokasi pedagang kaki lima di Kawasan Simpang Lima dan Jalan Pahlawan Kota Semarang. Economics Development Analysis Journal, 1(2), 1-6. https://doi.org/10.15294/edaj.v1i1.489

Indira, D. (2014). A study of street vending across the globe. International Journal of Advanced Research in Computer Science and Software Engineering, 4(9), 514519.

Kementerian Dalam Negeri. (2012). Peraturan Menteri Dalam Negeri Republik Indonesia No. 41 Tahun 2012 tentang Pedoman Penataan dan Pemberdayaan Pedagang Kaki Lima. Jakarta: Kementerian Dalam Negeri RI.

McKenzie, D., \& Seynabou Sakho, Y. (2010). Does it pay firms to register for taxes? The impact of formality on firm profitability. Journal of Development Economics, 91(1), 15-24. https://doi.org/10.1016/j.jdeveco.2009 .02 .003

Moleong, L. J. (2012). Metodologi penelitian kualitatif. PT. Remaja Rosdakarya.

Novita, I. (2016). Analisis dampak relokasi pasar tradisional pada padagang (Studi kasus Pasar Karangampel Indramayu tahun 2015). Institut Agama Islam Negeri (IAIN) Syekh Nurjati Cirebon.

Prasetya, M. A., \& Fauziah, L. (2016). Dampak sosial ekonomi relokasi pedagang kaki lima di Kecamatan Buduran Kabupaten Sidoarjo. JKMP (Jurnal Kebijakan Dan Manajemen Publik), 4(2), 135-150. https://doi.org/10.21070/jkmp.v4i2.69 1

Purnomo, R. A. (2016). Dampak relokasi terhadap lingkungan sosial pedagang kaki lima di Pusat Kuliner Pratistha Harsa Purwokerto. Ekuilibrium, 11(1), 1-9.

https://doi.org/10.24269/ekuilibrium.v 11i1.107

Rahayu, Y., Putra, A., Nurdin, Mayesti, I., Nelly, I., \& Daniel, P. A. (2019). Dampak relokasi pasar bagi pelaku ekonomi di Kota Jambi. Journal Development, 7(1), 15-128.

Rothenberg, A. D., Gaduh, A., Burger, N. E., Chazali, C., Tjandraningsih, I., Radikun, R., Sutera, C., \& Weilant, S. (2016). Rethinking Indonesia's Informal Sector. World Development, 80, 96-113. https://doi.org/10.1016/j.worlddev.20 15.11.005

Sugiyono. (2015). Metode penelitian kuantitatif kualitatif dan R\&D. Alfabeta.

Susilowati, N., \& Wangi, N. B. S. (2017). Kewirausahaan. Ahlimedia Book.

Widyaningrum, N. (2009). Kota dan Pedagang Kaki Lima. Jurnal Analisis Sosial, 14(1), 1-18. 
Yusuf, A. M. (2017). Metode penelitian:

Kuantitatif, kualitatif, dan penelitian gabungan. Kencana. 